\title{
4
}

\section{BETWEEN HOPE AND DESPAIR}

\section{Epistolary evidence of the emotional effects of persecution and exile during the Thirty Years War}

\section{Ole Peter Grell}

OPEN UNIVERSITY

The representatives of two large groups of Calvinist refugees from the Upper and Lower Palatinate who were exiled in and around the cities of Nuremberg and Hanau during the Thirty Years War kept up a considerable correspondence of several hundred letters with their sister-communities across Europe. These letters are a mix of 'private' and public statements written on behalf of the exiles to fellow Calvinist communities or individuals across Europe and the responses they received, covering a period of more than two decades. They were primarily written in Latin, but include a fair number of letters in French and Dutch too. ${ }^{1}$

The group of writers, not surprisingly, changed over time. Some died, others moved away or found new places of refuge, but a remarkable number remained in place for most of the period. The majority were Calvinist ministers, but a number were laymen who had served the Calvinist churches in the Palatinate prior to their exile. This was the case with the former Palatinate councillor and Doctor of Laws, Johann Jacob Heber from Amberg, who played a major part in the relief work for the refugees from 1626 until his death in 1634, and the former judge from Weissenohe in the Upper Palatinate, Jonas Liebing, who was prominent from 1631 till 1638. The letters are primarily concerned with requests for financial assistance and grateful acknowledgements of support given. Even so, they offer significant insights into the emotional effects of persecution and exile during the Thirty Years War.

The recipients of the letters used here were the members of the consistory of the Dutch Reformed Church in London (i.e. its twelve elders and three ministers). From 1628, more specifically, the recipients were the minister Wilhelm Thilenius and the three elders, Cornelius Godfrey, Abraham Beck, and John de Moncy, who had been given special responsibility for the money collected in the First Royal Collection in England for the Calvinist refugee ministers, schoolmasters, and their families from the Palatinate. ${ }^{2}$ Thilenius was by then the 
most junior of the ministers to the London Dutch Church, having been appointed in 1623, but he had the virtue of being well acquainted with English society and the Church of England, having attended Thomas Gataker's Puritan 'academy' in Surrey while training for his subsequent ministry in the Netherlands. He was assisted by Cornelius Godrey, who had become an elder twelve years earlier and belonged to the Dutch merchant-aristocracy, which had a virtual monopoly on the London eldership. Godfrey, like his colleague Abraham Beck, was a member of the English East India Company, but unlike Godfrey, Beck was a recent arrival from Germany who had only just been elected to the eldership. John de Moncy had become an elder in 1621 but was a longstanding member of the London congregation and through marriage belonged to one of the wealthiest London merchant families, the Courtens. In 1630, Beck and De Moncy were joined by John la Motte and Dirick Hoste, who had joined the eldership in 1626 and 1628 respectively, to take responsibility for the Second Royal Collection. Like their colleagues, La Motte and Hoste were wealthy merchants but belonged to a younger generation.

The letters, when received by the Dutch Reformed Church in London, were most likely read out either partly or in total in the first meeting of the consistory following their receipt. It is clear from the consistory books that the letters were discussed in detail, and we can safely presume that some of their more dramatic content was brought to the attention of the wider community via the subsequent sermons by the Dutch ministers. Unfortunately, no sermons have survived in manuscript or print. This is hardly surprising, when it is borne in mind that only a few Reformed or Calvinist sermons were published in the early modern period. ${ }^{3}$ Some indication of the way the information in the letters is likely to have been communicated to the wider community can, however, be gleaned from a number of the fast sermons that were preached to the House of Commons in the early 1640s and subsequently published.

But how do we go about teasing out the emotions of these individuals and communities from the epistolary evidence, and how was it received and interpreted? In this I find Barbara Rosenwein's book, Emotional Communities in the Early Middle Ages, with its concept of 'communities of emotion', particularly useful. ${ }^{4}$ Rosenwein underlines the modes of emotional expression that characterized and shaped groups such as high-ranking churchmen in the early Middle Ages. Such modes or shared norms undoubtedly also framed the emotions and the expression of the groups of Reformed refugees with which we are concerned here. The timeframe of twenty-plus years may seem somewhat short compared with both Rosenwein's and Karant-Nunn's, but that is to a large extent balanced out by the wider historical context in which the Palatine refugees located their emotional experience.

The persecuted, refugee Calvinists from the Palatinate shared their experience with fellow Reformed exiles in both historical and biblical terms. This is evident from the first letter referring to the need and misery of Calvinists from the 
Palatinate, which reached the Dutch Church in London in September 1624. Asking for financial assistance for exiled students from the University of Heidelberg, the professors of theology in Leiden stated:

You know that the more Antichrist endeavours to ruin the Church of Christ, the more pious Christians should labour to edify it. God the Almighty will move the hearts of our Dutch and English brothers to that. ${ }^{5}$

This apocalyptic interpretation was typical of how these tragic events in Germany were interpreted by fellow Calvinists across Europe, an explanation, initially at least, shared by the exiles themselves. Writing in the autumn of 1626 the exiles in and around Nuremberg promised to pray and 'heartily request God', who had generously given them both spiritual and material support, to preserve the London Dutch Church 'against the false teachings of Antichrist' that threatened their own existence. ${ }^{6}$ It is, however, noteworthy that this apocalyptic interpretation of their situation only seems to have featured prominently at the start and end of their exile. Obviously, the emotionally charged feelings and atmosphere linked to the end of time and the apocalyptic battle between good and evil were difficult to maintain over time.

During the first years of their exile, the Calvinist refugees bore their fate with patience and hope. When writing to the Dutch community in London thanking them for their recent letters and assistance, they not only told them that it 'was to us like bread from heaven', a simultaneous reference to both the physical bread, manna in the wilderness from the Book of Exodus 16:4, and 'the true bread from heaven' from John 6:32, meaning spiritual food. They added that they 'bore the rod of the Lord' (i.e. their persecution and exile) 'with filial patience'. That patience clearly came from the conviction of belonging to God's chosen people who were being tried and tested.

My title identifies two dominant and opposed emotions between which the exiled Calvinists from the Palatinate oscillated: hope and despair. To that should probably be added a third, which often manifested itself in connection with the latter, namely fear. Bearing in mind that the exiles belonged to a group of people who considered themselves to be among the elect, predestined to be saved, it is surprising to what extent their emotions were affected by fear and how much political and military developments shaped their moods.

Initially, in 1628, a certain amount of optimism among the exiles from the Palatinate persisted despite their deprivation and suffering, not to mention the grim prospects for a quick return to their homelands. The refugees from the Lower Palatinate in and around Hanau felt cheered up by the fact that the responsibility for the Royal Collection in Britain had been given to the Dutch Church in London whom they considered kindred to themselves not only in terms of nationality, but also in having shared their experience of persecution and exile. ${ }^{7}$ Despite being grateful for the assistance offered, the exiles from the Upper Palatinate in and around Nuremberg found it difficult to muster much optimism, describing themselves as 'miserable exiles of the 
Palatinate deprived of everything, assailed by the Papists, and neglected by their Lutheran neighbours'. ${ }^{8}$ Their pessimism may well have been generated by the fact that their host, the Lutheran city of Nuremberg, demonstrated a somewhat ambivalent attitude towards them, as on the one hand fellow persecuted Protestants who had to be helped, and on the other as heterodox co-religionists, excluded from the Peace of Augsburg, who might prove a threat to their existence. By the beginning of 1629 their mood had become even bleaker, and to a detailed description of their many sufferings they added:

To aggravate our misery we have to seek refuge among those who differ from us in religion and whose treacherous favour we must beseech and buy. And yet we do not escape mockery and calumny. ${ }^{9}$

The situation obviously looked bleak for the Reformed refugees at this stage when the Emperor and his Catholic allies had more or less defeated all Protestant forces within the Empire. They were evidently aware of the rumours circulating about proposed legal measures against members of the Reformed faith within the Empire, who had not been included in the 1555 Peace of Augsburg. Their fear of being expelled from the Empire was to some extent realized with the publication of the Edict of Restitution a couple of months later on 6 March 1629, which banned all Protestant denominations apart from Lutheranism within the Empire. ${ }^{10}$

The elders and ministers in London realized that something had to be done in order to help lift this growing despair among the refugees from the Upper Palatinate in particular. They quickly responded with extra funds and supportive words, stating that 'one hope, the hope of Israel, binds us all together, though we live far apart', while adding in another letter the following day that 'it is the duty of Christians not only to sympathize with the evil lot of their brethren, but to relieve the want as much as possible'. This statement that the godly were united irrespectively of where they resided also emphasized the obligation to realize the emotional bonds between these communities through physical and financial assistance.

The unity of the godly and the shared experience of persecution and exile was emphasized by the ministers in Hanau who oversaw the distribution of the help for the refugees from the Lower Palatinate. They pointed out to their London colleagues that they, of course, were familiar with 'what inconveniences an exile of this kind brings with it, as the remembrance of the afflictions which befell the churches of your country last century is still fresh in your memory'. ${ }^{11}$ This was to be the first of many references to the significance of the Marian exile that served to establish "a community of emotion" between Calvinists based in England and their suffering brethren within the Empire.

Even so, the letter from Hanau had an air of despair about it, emphasizing the misery the exiles suffered, having lost all their worldly possessions and being forced to flee only to find that their new neighbours showed them little or no charity. ${ }^{12}$ 
1629 proved a particularly difficult year for the Palatine refugees with more exiles arriving daily in Nuremberg and Hanau. The pressure on the refugees' meagre resources was growing exponentially, while political considerations meant that they could not stop providing some assistance to refugee Lutherans from Austria and Bohemia for fear of antagonizing local Lutherans on whose goodwill they depended. A sense of fear and foreboding permeates the letters written during 1629, and as the leaders of the refugees from the Lower Palatinate put it, they clearly lived in fear of worse to come. ${ }^{13}$ The ministers and elders in London were repeatedly reminded of the hospitality offered to the Marian exiles in the previous century in the Palatinate. The refugees used all the emotional pressure they could mobilize in order to influence their benefactors in London, reminding them of their distress and suffering, while claiming to "pray daily to the Lord that He may lead us back to our fatherland'. ${ }^{14}$

The autumn of 1629 proved particularly traumatic for the refugees. Their resources were virtually exhausted, many were starving and ill without any prospect of medical assistance, while the Catholic armies made it impossible for the exiles to seek shelter anywhere else. ${ }^{15}$ Sympathy was readily available in London. The Dutch ministers and elders grieved over the 'vastness' of the exiles' misfortunes and identified with their 'fear' of worse to come. ${ }^{16}$ Throughout 1630, the stress and fear of the Palatine exiles showed no sign of abating. Their letters emphasized their growing distress caused by extended exile and poverty, and as they wrote to their Dutch friends in London in February 1631: 'After God our chief hope is fixed on you'. 17

In August 1631, the exiles from the Upper Palatinate described their sufferings in detail in an open letter to the people of England, an initiative closely linked to the fundraising for the Second Royal Collection begun in the previous year. Having been 'despoiled and robbed by the hirelings and soldiers of Antichrist', they had been reduced to extreme poverty. They were despairing, seeing 'popery' growing in strength while fearing that 'the pure Gospel' would be extirpated or banished. They pointed out that God and the charity of the foreign churches now remained their only refuge, adding that they hoped the English would remember the hospitality and welcome the Palatinate had extended to those who fled the persecution in the time of Queen Mary. This appeal to shared experience and reciprocity of charity was clearly built on the assumption of the existence of a community of emotion and understanding between donors and receivers, even if the former needed constant reminding. ${ }^{18}$

Some optimism and hope among the Reformed refugees began to materialize during the autumn of 1631 as a consequence of the intervention on the Protestant side by the Swedish King, Gustavus Adolphus. This was especially so when Gustavus Adolphus crowned a string of victories over Catholic Imperial forces with the crushing defeat of Tilly's army at Breitenfeld on 17 September $1631 .{ }^{19}$ Optimism, however, initially appears to have been confined to the refugees' benefactors in London, who when they expressed the hope that God would restore the refugees to their homeland, added that there now seemed to be hope 
this would shortly come to pass. A fortnight later they expressed the hope that God would 'favour the sword of the King of Sweden and restore you to your country'. 20

Even if recognizing the military success of Gustavus Adolphus, the refugees from the Upper Palatinate did not share the optimism and hope of their benefactors in London. Instead they emphasized the increased dangers and suffering to which the large armies now operating around Nuremberg exposed them. They concluded that 'even if there were any hope, which is now faint, of our being restored to our country, we should find nothing but ruined homesteads and destitution'. Their fellow exiles from the Lower Palatinate were only marginally more optimistic, admitting that they now had more hope of being able to return home than before. ${ }^{21}$ However, by February 1632, hope was rapidly gaining ground among the refugees. The exiles from the Upper Palatinate thanked the Dutch Church in London for their support and expressed the hope that it would continue, for even though they expected to be freed from their long exile and to see their country delivered from 'the enemy and Papal darkness', their deliverance had yet to begin, while Catholic armies were still devastating their homeland. The exiles from the Lower Palatinate evidently felt more exuberant about the prospect of a return to their homeland, comparing it with 'the joy which the captives of Babylon felt at their unexpected delivery'. ${ }^{22}$ By May, the refugees from the Upper Palatinate felt similarly hopeful for an immediate return, thanks to the victories of Gustavus Adolphus over the Duke of Bavaria.

This optimism and hope for an immediate restitution, however, proved short lived. Already by the first weeks of May, the exiles from the Lower Palatinate were once again despairing, despite all the splendid victories of the King of Sweden and the arrival of their ruler, the Elector Palatine and King of Bohemia. They claimed that their 'evils' had been augmented rather than alleviated, and while the King of Sweden was fighting in Bavaria, Imperial armies were devastating the Palatinate. The refugee community was also badly affected by disease and high mortality rates. This was all the result, as they put it, of 'a most righteous God avenging the apostasy and faithlessness of the people of the Palatinate'. ${ }^{23}$ God was in other words punishing his chosen people, but that recognition gave little cause for cheerfulness at this point. Praising the Dutch community in London for its 'liberality and zeal for the exiles of Christ', which it demonstrated by adherence to the apostolic precept of assisting the Saints in times of need (Romans 12:13), the refugees from the Lower Palatinate highlighted their sad condition. They were not only 'oppressed by the tyranny of the Imperial forces, but the licentiousness of the Swedish soldiery was so great that they hardly knew who their friends were'. As they put it, 'hence there is no security; the fields are lying uncultivated and the ministers, who have returned to their churches, do not receive their stipends, the Swedes taking possession of everything. ${ }^{24}$ Their London benefactors expressed their sympathy, stating that 'blessed are those that suffer persecution for the sake of righteousness'.

The sense of fear and despair grew during the second half of 1632. The refugees in and around Nuremberg thanked God for still remembering them in this city of woe'. They wanted to send their benefactors in London a special letter of thanks, 
'unless famine and pestilence, which is raging in the midst of our civil war, should prove fatal to us. ${ }^{26}$ Little changed among the Reformed exiles from the Upper Palatinate during 1633, and what hopes they might have had after the Swedish intervention in the war had evaporated. As the Nuremberg refugees expressed it: they desired rather than expected a restitution, but their situation remained doubtful and sad, threatened as they were on all sides and exposed to 'freebooting and incendiarism'. The countryside around Nuremberg was devastated and they felt exposed to Imperial, as well as Swedish troops, who all intended to rob them (Figure 4.1). Nor for that matter, were they convinced that the Swedes, as Lutherans, were fully committed to assisting the Reformed. ${ }^{27}$ They lingered, as they put it, between hope and fear. ${ }^{28}$

The refugees from the Lower Palatinate proved more optimistic, especially since some of them had been able to return to their home country by mid1633. As God's chosen people, they felt this was like the Israelites returning to Canaan after their stay in Egypt, viewing the charity they had received from England as 'Dew of Manna'. They claimed that they would always remember

the awful and wonderful Justice, Goodnesse, Truth and Power of God. For just wee found God in punishing the sinnes of his sonnes; good in defending and maintaining them; true in keeping his promises; wise in leading and guiding wonderfully all his Saints; potent also in bowing and turning not only the hearts of all our neighbour churches, but likewise of them in the whole world dispersed, to be beneficial towards us poore, miserable, exiled Palatine men'. ${ }^{29}$

The refugees from the Upper Palatinate despaired and by mid-July 1634 reached a new low. After ten years of exile in Nuremberg, they were on the verge of giving up all hope for a return to their homeland and felt so upset by having to look out for a new abode that they struggled to write to their benefactors, referring them to Jeremiah 4:20-30 as a description of their condition. Evidently, Jeremiah's lamentation for Judah, which described God's judgement upon the Jews, provided an apt description of the situation of the godly refugees living under the New Covenant. ${ }^{30}$ The defeat of the Protestant forces in the battle of Nördlingen in September 1634 added further to their misery. ${ }^{31}$

Gradually towards the end of the 1630s, hope rather than fear and despair eventually got the upper hand among the refugee, Reformed communities, even if the Dutch community in Hanau still lamented in April 1638 the condition into which

the Lord had allowed His people in Germany to fall; how small the number of the righteous were; what famine, dearness, diseases, wars, bloodsheds have assailed the little ship of Christ; and what a sharp northwind has blown through this pleasure-garden of the Lord, all on account of men's sins. ${ }^{32}$ (Figure 4.2) 


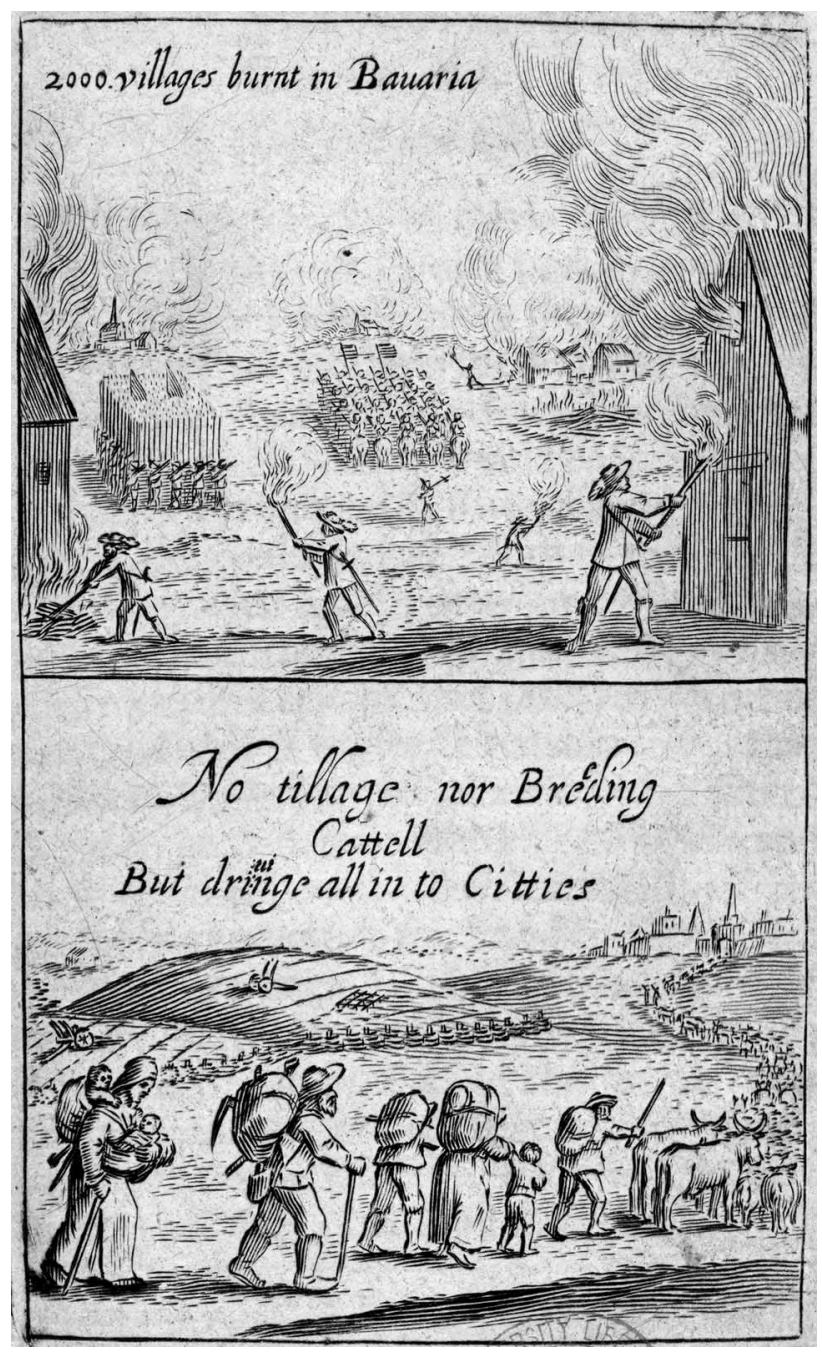

FIGURE 4.1 The devastation of the countryside by soldiers forcing civilians to flee to the cities, woodcut, in Philip Vincent, The Lamentations of Germany. Wherein, as in a Glasse, We May Behold Her Miserable Condition, and Read the Woefull Effects of Sinne. Composed by Dr Vincent Theol. An Eyewitnesse Thereof; And Illustrated by Pictures, the More to Affect the Reader (London, 1638), 32. Reproduced by kind permission of the Syndics of Cambridge University Library, Acton.d.sel.61.

Though the refugees in Nuremberg still thought they lived 'between despair and hope', by January 1640 they had to admit that they now experienced 'that the Lord watches over us'. Similar positive notes were struck by the minister Peter Crugoth, who wrote on behalf of the exiles from the Lower Palatinate a month later: 


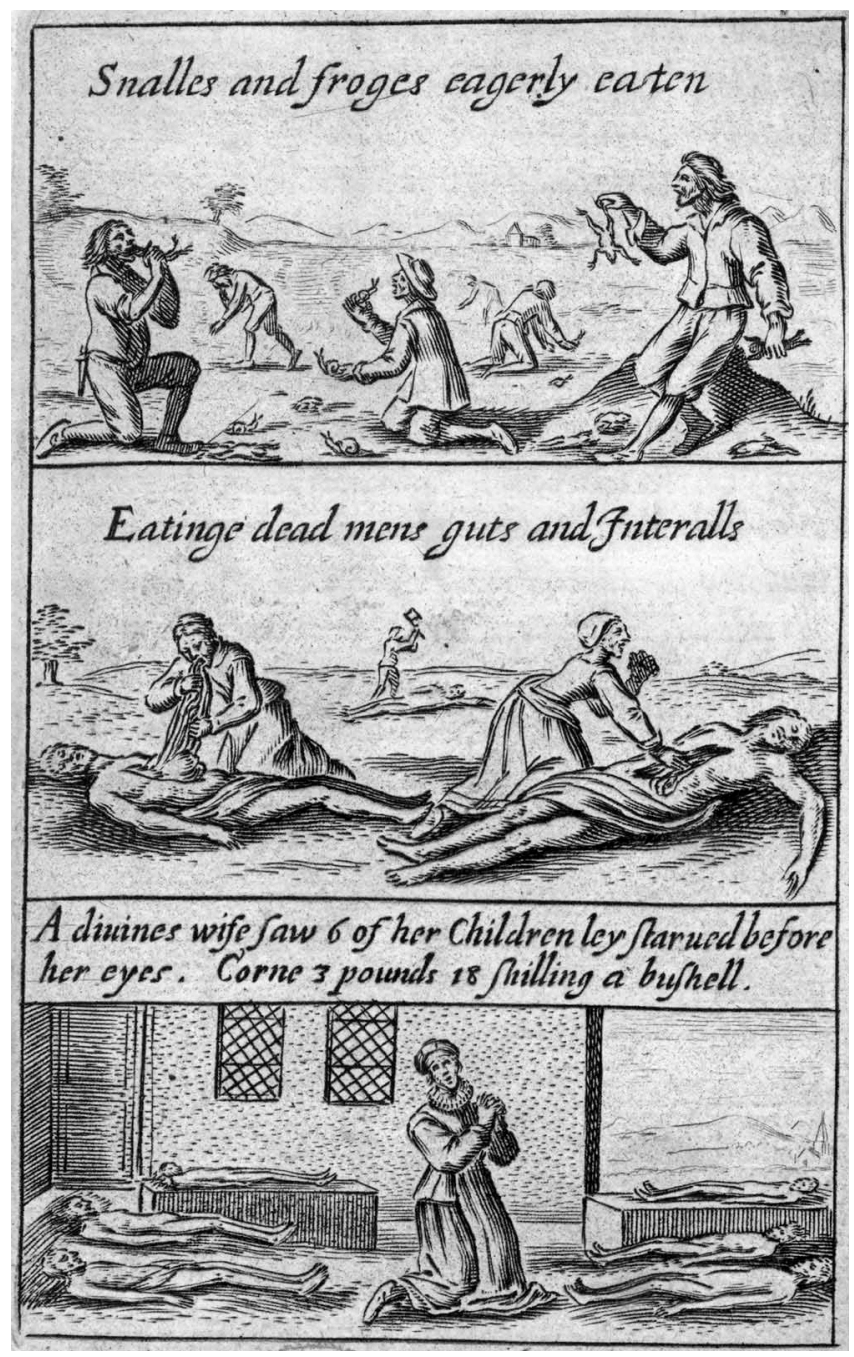

FIGURE 4.2 The desperate effects of famine, woodcut, in Philip Vincent, The Lamentations of Germany. Wherein, as in a Glasse, We May Behold Her Miserable Condition, and Read the Woefull Effects of Sinne. Composed by Dr Vincent Theol. An Eyewitnesse Thereof; And Illustrated by Pictures, the More to Affect the Reader (London, 1638), sig.A1v. Reproduced by kind permission of the Syndics of Cambridge University Library, Acton.d.sel.61.

Whenever we look at the varied condition of the church fighting under the banner of Christ, we cannot help wondering at seeing it exalted in one place, humiliated in another. Our own Church of the Palatinate is an example: formerly it flourished, now it is depressed and prostate. But we realize that the Lord's dispensation is most salutary, as, by humiliating his faithful, He prepares them for greater honours. ${ }^{33}$ 
God's punishing rod was evidently easier to bear with a more hopeful outlook for the future, but less salutary when prospects were bleak. A feeling that things had changed for the better by the late 1630s is illustrated by the number of requests for support that reached London for rebuilding Reformed communities and churches in places such as Hanau, Frankenthal, and Frankfurt. ${ }^{34}$

Together with a hope for better things to come, the letters written by the Reformed refugees from the summer of 1640 onwards also demonstrate a growing concern for the political and religious developments in Britain. Thus, the refugees from the Lower Palatinate, when thanking the Dutch church in London for its continuing generosity, ended their letter by expressing this wish: 'May the Lord reward you and settle the Scottish affair'. This was a reference to the outbreak of the Second Bishops' War, in which the Scots had just crossed the river Tweed and were marching on Newcastle. Evidently, the shared emotional community had not only biblical and historical roots to draw on but gained added importance and strength when they felt themselves linked to political events in Britain as well as Germany.

The exiles in Nuremberg expressed the firm hope in December 1640 that their 'afflictions' were finally coming to an end, while they referred to the peace negotiations between the Scottish Covenanters and King Charles, started a couple of months earlier, and joined their English benefactors in praying to God that the good beginnings lately observed in Great Britain might come to a happy conclusion. Rather inconsiderately, they added that such an outcome would be very much to their own benefit. ${ }^{35}$

Somewhat prematurely the exiles from the Lower Palatinate praised King Charles for having acted prudently 'by extinguishing the sparks of the dangerous flame' that could have led to civil war, pointing out that had their own princes done the same 'Germany would not be in such a plight'. ${ }^{36}$

By February 1642, the Reformed refugees in Nuremberg were aware of the growing confrontation between King Charles and Parliament, which would develop into a full blown civil war later in the year. They expressed their sorrow for the 'disturbed state of your country' and their concern over 'the cruel persecutions of the members of the Faith in Ireland'. ${ }^{37}$ Evidently, news of the rebellion of Irish Catholics in October 1641 and the accompanying atrocities committed against Protestant settlers in Ulster travelled fast among the Reformed communities, fed by the stream of lurid and sensationalized broadsheets that were published in London from November onwards. ${ }^{38}$

While deeply preoccupied with their own difficulties and their apocalyptic significance for which they found evidence in the Book of Daniel, the exiles from the Lower Palatinate still found space and time to mention that they prayed to God that 'He may pacify your Kingdom and Ireland'. They would have agreed with the Reformed refugees congregated around Zweibrüggen who wrote a couple of months later: "While in your England after the example of our own Country, preparations for war are made, and Ireland contrives something wicked against the brethren of our Faith' ${ }^{39}$ Shared 
misery and exposure to war served to emphasize the existence of an emotional community.

When in July 1642, the refugees from the Lower Palatinate wrote one of their last letters to their benefactors in London, they wondered why the Reformed Church now found itself in such a deplorable condition and why the preaching of the Gospel was no longer conducted as it had been at the start of the Reformation. They concluded that the darkness that was closing in on the godly had been brought about by sin, that had destroyed so many kingdoms and communities throughout history. However, they added the positive observation that 'what is a plague and punishment to sinners is a probation and exercise of virtue to the true Christian'. They obviously saw themselves in this light together with their benefactors and supporters in England. Quoting both Isaiah 66:12 and Daniel 4:24, they explained that they not only prayed to the Lord to reward the English for their sustained benevolence towards them, but also 'to calm the unrest and discord in England'. ${ }^{40}$

Such views and emotions were reciprocated by English Calvinists, as can be seen from a number of pamphlets published in the 1630s but in particular from some of the fast sermons preached to the House of Commons from the end of 1641 through the first months of 1642. Pamphlets such as The Lamentations of Germany by the minister Philip Vincent emphasized the emotional impact the suffering of the godly in Germany should have on their co-religionists in England:

Behold here, as in a Glasse, the mournefull face of a sister Nation, now drunke with misery; according to what God threatened by the Prophet Ieremy. Should I endeavour by all the memorable particulars, which might be accumulated, to amplifie this sad theme, the third part would bee sufficient to weary thee or blinde thy eyes with teares, if thy heart were not domant. ${ }^{41}$

In December 1641, the Presbyterian minister Edmund Calamy (1600-1666) preached a fast sermon to the House of Commons. Entitled England's lookingglasse, the sermon contained a stern warning to the MPs. Calamy held up events in Germany in general and in the Palatinate and Bohemia in particular, as a warning to the people of England to mend their ways before it was too late. The recent 'bloody' rebellion in Ireland emphasized that action was needed because the sword of the God was now hanging over England as a warning. Calamy emphasized the seriousness of the situation when he concluded:

Some Nations are chastised with the sword, Others with famine, Others with the man-destroying Plague. But poore Germany hath been sorely whipped with all these three iron whips at the same time, and that for above twenty years space. Oh, let us make use of this Bucket, and draw out water, and poure it out before the Lord this day; let us send up our 
cries to Heaven for Germany. It is a signe that we are not true members of the body of Christ, because we have no fellow-feeling of the miseries of the same body. A dead member hath no sense of its own misery, or of the bodies distemper. If wee be living members we will sympathize with the calamities of God's people. ${ }^{42}$

Evidently, only by feeling directly emotionally involved with their brethren in Germany could the English demonstrate that they too belonged to the godly.

Calamy was able to return to this subject a few months later when he delivered yet another fast sermon to the House of Commons, this time entitled Gods free mercy to England. He reminded the MPs that repentance was urgently needed:

First the judgements of God upon England: may wee not say who gave up England for a spoyle and Ireland unto Robbers? Hath not the Lord against whom we have sinned? Therefore hath he powred upon us the fury of his anger, and the strength of the Battell, it hath set us on fire round about, yet we carry ourselves as though we knew it not, and though it burnes we lay it not to heart and these shaking Judgements may the rather move us because this concussion is first universall, the disease is Epidemicall, this shaking began in the Palatinate, Bohemia, but it hath spread it selfe over France, Spaine and all the Christian World, the Lord seems to have a controversie with all Nations, \& to plead with all flesh, giving up a wicked World to the sword, as hee threatened before the ruine of Ierusalem. ${ }^{43}$

Similar sentiments were expressed by his colleague Stephen Marshall (1594-1655), who preached yet another fast sermon to the MPs on that day. Marshall had, however, already given similar, if somewhat more circumspect, warnings in a fast sermon to the House of Commons more than a year earlier. ${ }^{44}$ This time round Marshall emphasized that sympathy alone for the suffering of their brethren in Germany fell well short of what was required. Such 'empty and barren wishes', according to Marshall, could easily be extended to anyone in distress and were of little or no value. More was required from the godly; feeling sorry for suffering fellow Calvinists in Germany and Ireland without any action fell short of what was required. Direct physical assistance was called for, be it in person or through a financial contribution-only in that way could the Saints prove their sincerity. ${ }^{45}$

Apart from demonstrating that English Calvinists sympathized with and shared in the persecution and suffering of the exiles, these fast sermons also exemplify how such news was communicated from the pulpit. As such, they are probably similar to sermons preached by other Calvinist ministers in the 1620s and 1630s, be they English or the ministers to the Dutch and French Reformed communities in England. 
Evidence of true godliness demanded not only emotional commitment, but direct action also. The behaviour and engagement of the Dutch elder and merchant, John la Motte, who was responsible for the Second Royal Collection, was clearly a model for the godly. John la Motte's extraordinary commitment to the 'Church of God' and his never-ending charity for suffering brethren in Christ featured prominently in his funeral sermon, as did his exceptional ability to inspire others to join the cause, by setting all who encountered him on a 'fire of compassion'. Every year, La Motte celebrated the anniversary of Queen Elizabeth's coronation by having his friends for dinner, not only to celebrate the mercy God had shown England on that day, but in particular to celebrate the 'grand Deliverances' of the godly, especially after the Reformation. Particular mention was given to:

... the great sufferings and bloody Persecutions in France, and the Low Countries, whereof he would often discourse in so punctuall and feeling manner, as if he had been an eye-witness, yea a sharer in them, taking many arguments thence of encouraging himself and others to be still mindfull of them in bonds and miseries, as being themselves in the body; saying, why, their case might have been ours, or may yet, who knows? ${ }^{46}$

In other words, good Calvinists did not have to have experienced persecution and exile personally to feel part of the emotional community of those who had suffered. Second-generation immigrants like La Motte, who was born in Colchester, could be just as deeply involved emotionally in the suffering and persecution, thereby possibly making their commitment even more impressive and convincing to others.

Life as a religious refugee during the Thirty Years War in Germany was a harrowing experience, and the emotional effects were serious. The Reformed exiles were seldom able to find sanctuary among co-religionists; instead, they had to seek shelter within Lutheran communities where they were at best reluctantly tolerated. The fact that the Reformed faith had not been included in the Peace of Augsburg meant that they had no legal protection within the Empire. In 1629, their situation was further undermined, when the Emperor issued the Edict of Restitution, which banned all Protestant denominations apart from Lutheranism. This severely aggravated their situation, putting them in danger of being forced to leave Germany while simultaneously putting pressure on their Lutheran hosts who by giving them shelter could be considered in breach of Imperial law.

The tenuous relationship between the Reformed refugees and their Lutheran hosts constantly fluctuated, driven by external political and military developments as much as by internal tension. The fact that their exile proved an extended one-lasting more than a couple of decades - undoubtedly served to make the situation of the exiles even more difficult, putting them under further strain. It certainly added to the fear and insecurity of the exiles who increasingly depended on the financial and moral support they received from foreign Calvinist communities. Not 
surprisingly, the exiles swung emotionally between hope and despair, with anxiety and despondency dominating their outlook for prolonged periods. The length of their exile combined with repeated disappointments made the refugees weary. Thus, it took them considerable time before they were prepared to share the optimism of their benefactors in London generated by the victories of the Swedish King Gustavus Adolphus. They did so only to face renewed disappointment when it turned out that the Swedish soldiers did them just as much damage as their Imperial enemies, and their hope for a return to their homelands proved premature.

Biblical examples of the Egyptian sojourn from the Book of Exodus, and of the Babylonian captivity of the Israelites from The Book of Daniel, provided the refugees with spiritual sustenance. For God had always tested his elect or chosen people. To that, they could add recent historical events such as the persecutions and exile of the Reformed in the Netherlands and France, not to mention the experience of the Marian exiles from England. By drawing on both biblical and historical examples, they were able to assure themselves that they shared a community of emotions with their brethren abroad. This shared community was further enhanced by the religious and political confrontation that was mounting in Britain from 1640 onwards. The fact that the battle between the godly and the ungodly once more came to be seen as 'universal' endowed these events with renewed apocalyptic significance. It would seem that a sense of election, of belonging to God's chosen people at the centre of the last apocalyptic battle between Christ and Antichrist, could not thrive without hope. Obviously, it proved difficult, if not impossible, for the refugees to maintain their optimism and hope of a return to 'the promised land'-their home country-as time went by, especially when their suffering dragged on or even took a turn for the worse. In that situation, anxiety and despair overwhelmed them and their letters were characterized by a deep pessimism and little if any indication of belonging to the elect. Even for Calvinists, who believed in predestination and their own election, it proved virtually impossible to maintain hope and a positive outlook when faced with prolonged displacement, intolerance, extreme poverty, and deep anxiety.

\section{Notes}

1 For these letters and their authors, see O.P. Grell, Brethren in Christ. A Calvinist Network in Reformation Europe (Cambridge: Cambridge University Press, 2011), 178-228. All quotations from these letters below that are in modern English are my own translations.

2 Grell, Brethren in Christ, 178-228.

3 Susan C. Karant-Nunn, The Reformation of Feeling: Shaping the Religious Emotions in Early Modern Germany (New York, Oxford: Oxford University Press, 2010), 101-32.

4 Barbara Rosenwein, Emotional Communities in the Early Middle Ages (Ithaca: Cornell University Press, 2006).

5 J. H. Hessels, ed., Ecclesiae Londino-Batavae Archivum, vol 3 in 2 parts (Cambridge, 1887-1897), no. 1833. 
6 Hessels, Ecclesiae Londino-Batavae, no. 1858.

7 Hessels, Ecclesiae Londino-Batavae, no. 1919.

8 Hessels, Ecclesiae Londino-Batavae, no. 1987.

9 Hessels, Ecclesiae Londino-Batavae, no. 1953.

10 O. P. Grell, Brethren in Christ. A Calvinist Network in Reformation Europe (Cambridge: Cambridge University Press, 2011), 152.

11 Hessels, Ecclesiae Londino-Batavae, no. 1963.

12 Hessels, Ecclesiae Londino-Batavae, see also no. 1964.

13 Hessels, Ecclesiae Londino-Batavae, no. 1981.

14 Hessels, Ecclesiae Londino-Batavae, no. 1994; see also nos. 1985 and 1987.

15 Hessels, Ecclesiae Londino-Batavae, nos. 2000 and 2003.

16 Hessels, Ecclesiae Londino-Batavae, no. 2005.

17 Hessels, Ecclesiae Londino-Batavae, no. 2069.

18 Hessels, Ecclesiae Londino-Batavae, no. 2100.

19 Grell, Brethren in Christ, 160.

20 Hessels, Ecclesiae Londino-Batavae, nos. 2128 and 2138.

21 Hessels, Ecclesiae Londino-Batavae, nos. 2134 and 2141.

22 Hessels, Ecclesiae Londino-Batavae, nos. 2148 and 2155.

23 Hessels, Ecclesiae Londino-Batavae, no. 2170.

24 Hessels, Ecclesiae Londino-Batavae, no. 2193.

25 Hessels, Ecclesiae Londino-Batavae, no. 2212.

26 Hessels, Ecclesiae Londino-Batavae, no. 2203.

27 Hessels, Ecclesiae Londino-Batavae, nos. 2223, 2225, and 2228.

28 Hessels, Ecclesiae Londino-Batavae, no. 2230.

29 Hessels, Ecclesiae Londino-Batavae, nos. 2239 and 2276.

30 Hessels, Ecclesiae Londino-Batavae, no. 2301.

31 Hessels, Ecclesiae Londino-Batavae, no. 2326.

32 Hessels, Ecclesiae Londino-Batavae, no. 2469.

33 Hessels, Ecclesiae Londino-Batavae, no. 2534

34 Hessels, Ecclesiae Londino-Batavae, nos. 2529, 2576, and 2585.

35 Hessels, Ecclesiae Londino-Batavae, no. 2598.

36 Hessels, Ecclesiae Londino-Batavae, no. 2616.

37 Hessels, Ecclesiae Londino-Batavae, no. 2660.

38 O.P. Grell, "Godly Charity or Political Aid? Irish Protestants and International Calvinism, 1641-1645," The Historical Journal 39, no.3 (1996): 743-53, especially pages 743-46.

39 Hessels, Ecclesiae Londino-Batavae, nos. 2661 and 2672.

40 Hessels, Ecclesiae Londino-Batavae, no. 2678.

41 Philip Vincent, The Lamentations of Germany. Wherein, as in a Glasse, We May Behold Her Miserable Condition, and Read the Woefull Effects of Sinne. Composed by Dr Vincent Theol. An Eyewitnesse Thereof; And Illustrated by Pictures, the More to Affect the Reader (London, 1638), To the Reader, sig.A3r. See also L. Brinckmair, The Warnings of Germany. By Wonderfull Signes and Strange Prodigies Seene in Divers Parts of That Country of Germany, Betweene the Yeare 1618 and 1638 (London, 1638).

42 E. Calamy, Englands Looking-Glasse (London, 1642), 33-34; see also 3.

43 E. Calamy, Gods Free Mercy to England (London, 1642), 24.

44 S. Marshall, A Sermon Preached before the Honourable House of Commons, Now Assembled in Parliament, at Their Publike Fast, Nov. 17 1640. Upon 2 Chron. 15.2 (London, 1641):

And secondly let mee beseech you all in this your great National Councel, and Assembly, to take seriously into your thoughts, what may be the best way of lengthening out our tranquillity. Beloved, all the Nations in Christendome have been in grievous perplexities many years round about us: we have been hitherto kept as another Land of Goshen, where light has still shined, when all others have been in darkness (p.19). Goshen was where the Israelites had lived while in Egypt and which had been exempted from the last seven plagues which hit the rest of Egypt, Exodus 8:22. 
45 S. Marshall, Meroz Cursed (London, 1642), 50.

46 Fulke Bellers, Abrahams Interment (London, 1655), F4r-4v, and F2v-F3r. See also O. P. Grell, Calvinist Exiles in Tudor and Stuart England (Brookfield, VT: Ashgate, 1996), 20-21.

\section{Bibliography}

Bellers, F. Abrahams Interment. London, 1655.

Brinckmair, L. The Warnings of Germany. By Wonderfull Signes and Strange Prodigies Seene in Divers Parts of that Country of Germany, Betweene the Yeare 1618 and 1638. London, 1638.

Calamy, E. Englands Looking-Glasse. London, 1642.

Calamy, E. Gods Free Mercy to England. London, 1642.

Grell, Ole Peter. Calvinist Exiles in Tudor and Stuart England. Brookfield VT; Aldershot: Scolar Press; Ashgate Publishing Company, 1996.

Grell, Ole Peter. "Godly Charity or Political Aid? Irish Protestants and International Calvinism, 1641-1645.” The Historical Journal 39, no.3 (1996): 743-53.

Grell, Ole Peter. Brethren in Christ. A Calvinist Network in Reformation Europe. Cambridge: Cambridge University Press, 2011.

Hessels, J. H., ed. Ecclesiae Londino-Batavae Archivum. Vol 3 in 2 parts. Cambridge, 1887-1897.

Karant-Nunn, Susan C. The Reformation of Feeling: Shaping the Religious Emotions in Early Modern Germany. New York, Oxford: Oxford University Press 2010.

Marshall, S. A Sermon Preached before the Honourable House of Commons, Now Assembled in Parliament, at Their Publike Fast, Nov. 17 1640. Upon 2 Chron. 15.2. London, 1641.

Marshall, S. Meroz Cursed. London, 1642.

Rosenwein, Barbara H. Emotional Communities in the Early Middle Ages. Ithaca: Cornell University Press, 2006.

Vincent, Philip. The Lamentations of Germany. Wherein, as in a Glasse, We May Behold Her Miserable Condition, and Read the Woefull Effects of Sinne. Composed by Dr Vincent Theol. An Eyewitnesse Thereof; and Illustrated by Pictures, the More to Affect the Reader. London, 1638. 